\title{
RELEVANSI KOMPETENSI LULUSAN DIPLOMA TIGA TEKNIK SIPIL DI DUNIA KERJA
}

\author{
Anas Arfandi \\ Pendidikan Teknik Sipil dan Perencanaan Universitas Negeri Makassar \\ anas_arfandi@yahoo.com
}

\begin{abstract}
Abstrak
Penelitian ini bertujuan untuk: (1) mendeskripsikan relevansi bidang kerja lulusan dengan latar belakang pendidikan mereka; dan (2) memetakan relevansi kompetensi D3 Teknik Sipil di dunia kerja dengan kompetensi D3 Teknik Sipil di FT UNM. Penelitian ini adalah penelitian survey. Populasi penelitian adalah seluruh lulusan D3 teknik sipil 5 tahun terakhir dan industri tempat mereka bekerja. Sampel yang diambil menggunakan proportionate random sampling dengan jumlah sampel 16 lulusan dan 9 industri. Data dikumpulkan menggunakan kuisioner dan wawancara terstruktur. Analisis data menggunakan deskriptif kualitatif. Hasil penelitian menunjukkan bahwa 1) relevansi bidang kerja lulusan dengan latar belakang pendidikan mereka Cukup Baik; dan 2) kompetensi di dunia kerja sudah relevan dengan kompetensi lulusan D3 teknik sipil FT UNM. Keterampilan teknis lulusan Cukup Relevan yang mencapai 73,68\%, namun masih terdapat 26,32\% yang sudah tidak relevan lagi. Pada keterampilan bekerja, sebagian besar lulusan mencapai tingkat Ahli, namun demikian keterampilan tersebut tidak diperoleh pada pembelajaran di perguruan tinggi melainkan mereka dapatkan setelah mereka bekerja.
\end{abstract}

Kata kunci: relevansi kompetensi, keterampilan teknis, keterampilan bekerja

\section{THE RELEVANCY COMPETENCIES OF CIVIL ENGINEERING DIPLOM THREE GRADUATES IN THE WORLD OF WORK}

\begin{abstract}
This study aims to: (1) describe the relevance of the graduates employment with their educational background; and (2) mapping the relevance of the graduates competencies with the competencies in the world of work. This studied is a survey research. The research population consisted of all graduates of D3 civil engineering FT UNM for last 5 years and the industries of graduates employment. Sampling using proportionate random sampling consisted 16 graduates and 9 industries. Data collected by questionnaire and structured interviews. Data was analysis used qualitative descriptive. The result shows that 1) the relevance of the graduates employment with their educational background was quite good; 2) the competency in the world of work was relevance to the competencies of the graduates of D3 civil engineering FT UNM. Graduates technical skills quite relevant for $73,68 \%$, but $26,32 \%$ was not relevant anymore. In employability skills, many graduates have achieve expert level, eventhought they have it not from the learning in the university but in the world of work.
\end{abstract}

Keywords: the relevancy competencies, technical skills, employability skills 


\section{PENDAHULUAN}

Relevansi pada pendidikan kejuruan bukan saja disebabkan oleh adanya kesenjangan antara "supply" dan "demand" semata namun bisa disebabkan oleh isi kurikulum yang kurang sesuai dengan tuntutan dunia kerja, perkembangan Iptek dan perkembangan ekonomi (Tilaar, 1991). Karena itu, pembaharuan pendidikan, kurikulum, dan pembelajaran harus selalu dilaksanakan dari waktu ke waktu dan tak pernah henti. Pendidikan, kurikulum, dan pembelajaran berbasis kompetensi merupakan contoh hasil perubahan dimaksud dengan tujuan untuk meningkatkan kualitas pendidikan dan pembelajaran (Mukminan, dkk, 2008). Kebutuhan akan tenaga kerja tersebut disediakan melalui pendidikan vokasional yang melatih dan mendidik siswa untuk dapat bekerja pada suatu bidang kerja tertentu, sehingga kebutuhan akan ketersediaan tenaga kerja. Education for life dan education for earning living merupakan dua konsep yang tidak bisa dipisahkan secara tegas (Finch \& Crunkilton, 1999).

Kondisi ketenagakerjaan di Indonesia yang saat ini masih diwarnai tingkat pengangguran yang semakin tinggi, dapat dikatakan bahwa lulusan perguruan tinggi masih lemah dalam memenuhi permintaan pasar tenaga kerja. BPS mencatat total jumlah pengangguran terbuka secara nasional pada Februari 2010 mencapai 8,59 juta orang atau $7,41 \%$ dari total angkatan kerja. Dari angka tersebut, pendidikan terakhir Diploma berada pada rangking teratas sebesar $15,71 \%$ diikuti lulusan universitas sebesar 14,24\% dan lulusan SMK sebesar 13,81\%. Pekerja pada jenjang pendidikan SD ke bawah masih tetap tinggi yaitu sekitar 55,31 juta orang $(51,50 \%)$ sedangkan jumlah pekerja dengan pendidikan tinggi masih relatif kecil. Pekerja dengan pendidikan Diploma hanya sebesar 2,89 juta orang $(2,69 \%)$ dan pekerja dengan pendidikan Sarjana hanya sebesar 4,94 juta orang $(4,60 \%)$ (BPS, 2010).

Berdasarkan fenomena di atas, masalah yang akan diteliti, yaitu: 1) Bagaimana kompetensi lulusan yang dibutuhkan dunia industri? 2) Bagaimana relevansi kompetensi lulusan dengan kompetensi di dunia kerja?

\section{METODE}

Jenis penelitian ini adalah penelitian survey. Variabel yang diperhatikan dalam penelitian ini adalah kompetensi lulusan D3 Teknik Sipil dan relevansi kompetensi. Kompetensi lulusan D3 Teknik Sipil adalah seperangkat keterampilan yang dimiliki oleh lulusan setelah menyelesaikan studi pada D3 Teknik Sipil dalam hal ini technical skills dan employability skills. Sementara relevansi kompetensi adalah kesesuaian seperangkat keterampilan yang dimiliki oleh lulusan dengan keterampilan yang dibutuhkan oleh dunia industri/perusahaan. Populasi penelitian adalah seluruh lulusan D3 teknik sipil pada 5 (lima) tahun terakhir dan industri tempat lulusan bekerja. Sampel yang diambil menggunakan proportionate random sampling dengan jumlah sampel sebanyak 16 lulusan and 9 industri. Data dikumpulkan menggunakan instrumen dengan metode wawancara terstruktur secara langsung yang berisi pertanyaan tertutup dan pertanyaan terbuka. Data dianalisis secara deskriptif kualitatif.

\section{HASIL PENELITIAN DAN PEMBAHASAN}

\section{Kompetensi Lulusan yang Dibutuhkan Industri}

Undang-Undang (UU) No. 13 tahun 2003 tentang Ketenagakerjaan pasal 1 ayat 10 menyebutkan bahwa kompetensi adalah kemampuan kerja setiap individu yang mencakup aspek pengetahuan, keterampilan dan sikap kerja yang sesuai dengan standar yang ditetapkan. Surat Keputusan Mendiknas Nomor 045/U/2002 tentang Kurikulum Inti Perguruan Tinggi dikemukakan bahwa kompetensi adalah seperangkat tindakan cerdas, penuh tanggungjawab yang dimiliki seseorang sebagai syarat untuk dianggap mampu oleh masyarakat dalam melaksanakan tugas-tugas di bidang pekerjaan tertentu.

Secara lebih spesifik, kompetensi lulusan pada penelitian ini dilihat pada aspek keterampilan teknis (technical skills) dan keterampilan bekerja (employability skills). Berikut disajikan gambaran kompetensi yang dibutuhkan industri konstruksi: 


\section{Technical Skills}

Technical skills yang dimasukkan terdiri atas 19 komponen skills yang masuk ke dalam kategori bidang pekerjaan administrasi dan pekerjaan lapangan. Beberapa kompenen Technical skills yang dibutuhkan industri secara detail dapat dilihat pada Tabel 1.

Tabel 1. Kebutuhan Technical Skills Industri

\begin{tabular}{|c|c|c|c|c|c|}
\hline No & Tugas & SB & CB & TB & STB \\
\hline 1 & Mengetahui bidang pekerjaan & 71,43 & 28,57 & & \\
\hline 2 & Menggambar manual & 14,29 & 42,86 & 28,57 & 14,29 \\
\hline 3 & Menggambar menggunakan computer & 57,14 & 28,57 & 14,29 & - \\
\hline 4 & Menghitung RAB secara manual (kalkulator) & 14,29 & 42,86 & 28,57 & 14,29 \\
\hline 5 & Menghitung RAB menggunakan computer & 57,14 & 28,57 & 14,29 & - \\
\hline 6 & Mengidentifikasi kesalahan perhitungan RAB & 57,14 & 14,29 & 28,57 & - \\
\hline 7 & Mengevaluasi kelayakan RAB & 57,14 & 14,29 & 28,57 & - \\
\hline 8 & Mengoperasikan Alat/Mesin & 14,29 & 42,86 & 42,86 & - \\
\hline 9 & Memelihara Alat/Mesin & - & 57,14 & 42,86 & - \\
\hline 10 & Memperbaiki Alat/Mesin & - & 57,14 & 42,86 & - \\
\hline 11 & Mengidentifikasi Kerusakan Alat/Mesin & 14,29 & 42,86 & 42,86 & - \\
\hline 12 & Membaca gambar kerja & 85,71 & 14,29 & - & - \\
\hline 13 & Menjelaskan gambar kerja kepada tukang & 71,43 & 28,57 & - & - \\
\hline 14 & Melaksanakan/mengawasi pekerjaan sesuai jadwal & 85,71 & 14,29 & - & - \\
\hline 15 & Membuat laporan pelaksanaan/pengawasan pekerjaan & 85,71 & 14,29 & - & - \\
\hline 16 & Merevisi kesalahan pada pekerjaan & 42,86 & 42,86 & 14,29 & - \\
\hline 17 & Mengevaluasi pelaksanaan pekerjaan & 71,43 & 14,29 & 14,29 & - \\
\hline 18 & Menyusun dokumen tender & 57,14 & 28,57 & 14,29 & - \\
\hline 19 & Melakukan pekerjaan survey & 71,43 & 14,29 & 14,29 & - \\
\hline
\end{tabular}

Sumber : hasil penelitian, 2011

Dari Tabel 1 memperlihatkan bahwa terdapat beberapa tugas-tugas yang tidak lagi dibutuhkan oleh Industri, baik dengan persentase yang kecil maupun persentase yang besar. Persentase terbesar tugas-tugas yang tidak lagi dibutuhkan sebesar $42,86 \%$ bahkan sangat tidak dibutuhkan yakni pada pekerjaan manual seperti menggambar dan menghitung $\mathrm{RAB}$, serta pada tugas-tugas yang berkaitan dengan peralatan dan pemesinan. Komponen technical skills yang tidak lagi dibutuhkan oleh industri, terkait dengan tugas-tugas yang terkait pekerjaan manual seperti menggambar dan menghitung $\mathrm{RAB}$, serta tugas yang berkaitan dengan peralatan dan pemesinan baik dalam hal pengoperasian, pemeliharaan, maupun perbaikan. Hal ini mengindikasikan bahwa pembelajaran di kampus sebaiknya tidak lagi menitik beratkan pada pekerjaanpekerjaan manual baik dalam teori maupun prakteknya sehingga mahasiswa lebih dibekali keterampilan-keterampilan yang bersifat komputerisasi, otomatisasi, dan modernisasi. Secara umum, kebutuhan technical skills oleh industri dapat dilihat pada Gambar 1. 


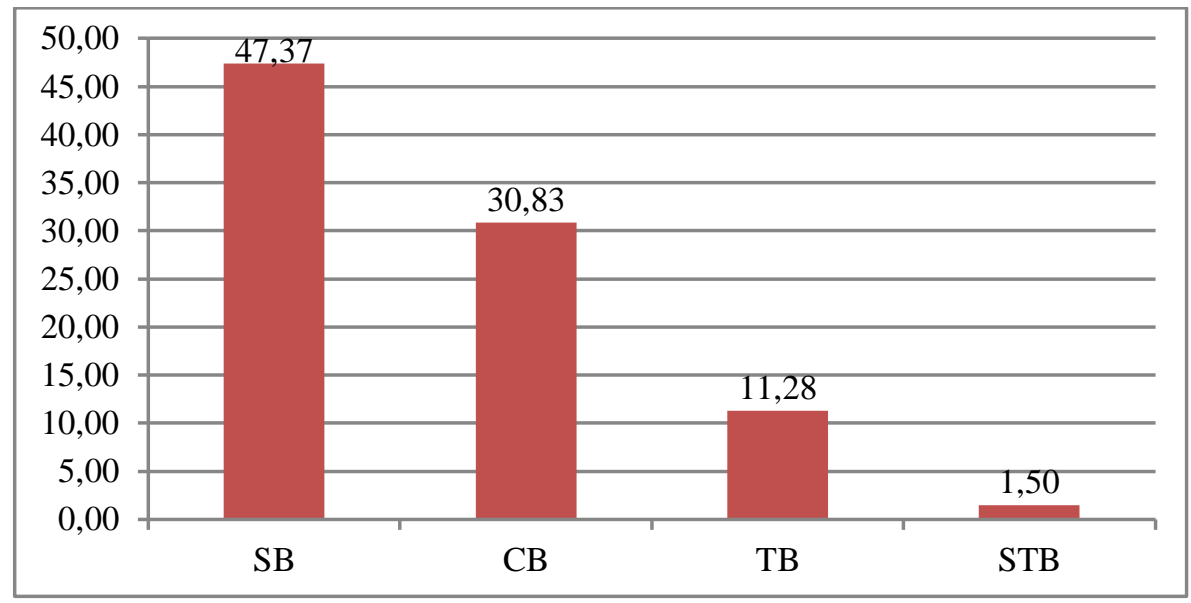

Gambar 1. Grafik Technical Skills yang Dibutuhkan Industri

SB: sangat butuh;

TB: tidak butuh;
CB: cukup butuh;

STB: sangat tidak butuh
Gambar 1 menunjukkan bahwa 47,37\% technical skills masih sangat dibutuhkan oleh industri, namun masih terdapat 11,28\% technical skills sudah tidak dibutuhkan, bahkan 1,50\% sudah sangat tidak dibutuhkan. Dengan hasil seperti ini, maka pihak perguruan tinggi sudah harus segera merevisi pembelajaran yang dilakukan dengan target pencapaian kompetensi yang disesuaikan dengan kebutuhan dan harapan dunia industri serta melihat perkembangan dunia kerja di masa yang akan datang.

\section{Employability Skills}

Komponen employability skills yang dibutuhkan industri yang terdiri dari 8 komponen. Beberapa kompenen employability skills yang dibutuhkan industri secara detail dapat dilihat pada Tabel 2.

Tabel 2. Komponen Employability Skills yang Dibutuhkan Industri

\begin{tabular}{lrrrr}
\hline \multicolumn{1}{c}{ Employability skills } & SB & CB & TB & STB \\
\hline Komunikasi & 71,43 & 26,53 & 2,04 & - \\
Kerja Tim & 62,50 & 32,14 & 3,57 & 1,79 \\
Pemecahan Masalah & 59,52 & 40,48 & - & - \\
Manajemen Diri & 58,93 & 41,07 & - & - \\
Perencanaan dan Pengelolaan & 58,93 & 39,29 & 1,79 & - \\
Teknologi & 57,14 & 42,86 & - & - \\
Belajar Sepanjang Hayat & 53,06 & 44,90 & 2,04 & - \\
Inisiatif dan Keberanian Berusaha & 67,86 & 32,14 & - & - \\
\hline Sur
\end{tabular}

Sumber: Hasil Penelitian, 2011

Komponen employability skills menunjukkan bahwa keterampilan komunikasi berada pada posisi tertinggi yang sangat dibutuhkan sebesar $71,43 \%$ yang selanjutnya diikuti keterampilan inisiatif dan keberanian berusaha, kerja tim, sampai pada keterampilan belajar sepanjang hayat. Namun demikian, terdapat juga komponen employability skills yang tidak dibutuhkan bahkan juga terdapat komponen yang sangat tidak dibutuhkan walaupun relative kecil yakni pada komponen keterampilan kerja tim, komunikasi, belajar sepanjang hayat, dan perencanaan dan pengelolaan.Untuk lebih jelasnya dapat dilihat pada Gambar 2. 


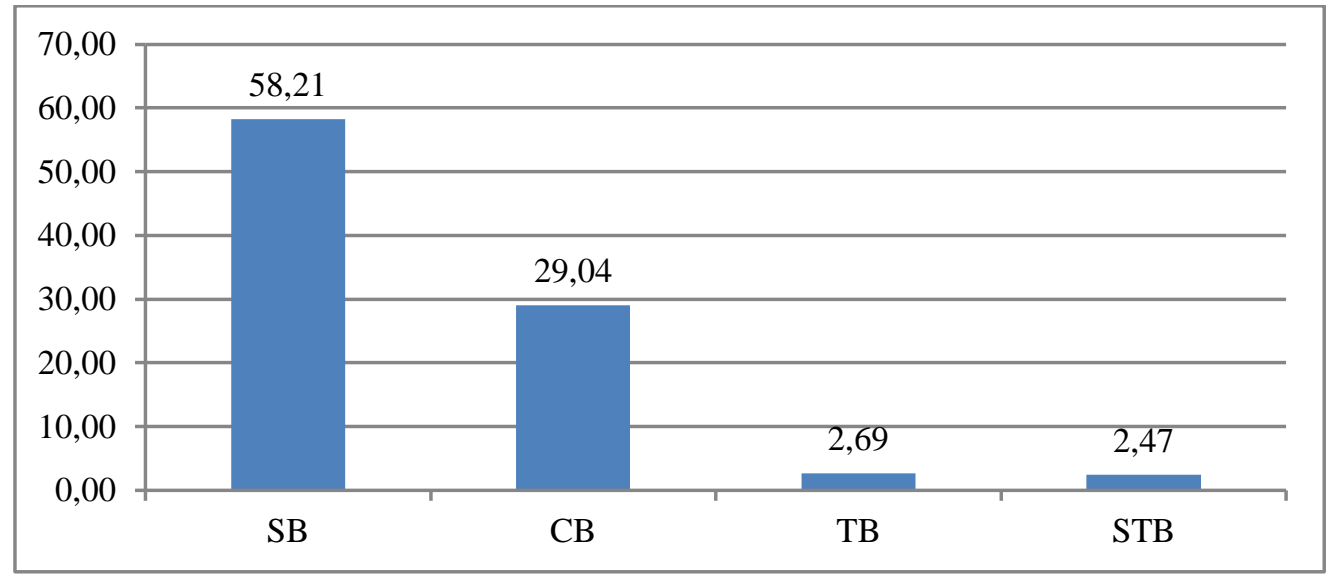

Gambar 2. Grafik Employability Skills yang Dibutuhkan Industry

SB: sangat butuh;

TB: tidak butuh;
CB: cukup butuh;

STB: sangat tidak butuh
Dari Gambar 2 diatas terlihat bahwa tingkat kebutuhan employability skills masuk pada kategori sangat tinggi mencapai $87,25 \%$. Hal ini terlihat pada poin sangat dibutuhkan sebesar 58,21\% dan cukup dibutuhkan sebesar $29,04 \%$. Namun demikian, masih terdapat $2,47 \%$ industri yang berpendapat bahwa $\mathrm{em}$ ployability skills sudah sangat tidak dibutuhkan. Secara detail, komponen employability skills yang tidak lagi dibutuhkan yakni pada indikator kerjasama tim yang didalamnya terdapat item kemampuan bekerja sendiri, individualis, dan merasa tidak membutuhkan bantuan orang lain. Hal ini dimungkinkan karena pekerjaan di dunia konstruksi merupakan pekerjaan yang saling terikat antara satu sama lain sehingga sangat sulit untuk bias bekerja sendiri. Beberapa industri yang beranggapan bahwa kemampuan bekerja sendiri masih dibutuhkan terutama pada bagian drafter, karena yang dibutuhkan adalah kemampuannya dalam mengerjakan sendiri tugastugas penggambaran bukan dengan meminta bantuan orang lain.

Hasil penelitian Benyamin \& Lanny (2002) menyebutkan 82 (delapan puluh dua) kriteria yang terbagi ke dalam 13 kelompok jika fresh graduate teknik sipil ingin menjadi site engineer pada perusahaan Kontraktor kelas A di kota Surabaya, yakni: (1) penguasaan ilmu-ilmu teknik sipil; (2) kemampuan membaca gambar teknik; (3) indeks prestasi kumulatif minimal 2,75; (4) bekerjasama dengan orang lain; (5) komunikasi dan presentasi; (6) profesional, komersial, dan praktek sistem kontrak; (7) mengelola proyek; (8) penguasaan teknologi informasi; (9) kemampuan memasarkan dan mempublikasikan; (10) mengelola keuangan proyek; (11) mengelola perusahaan; (12) kesehatan dan keselamatan kerja; dan (13) mengelola kualitas. Tingkat kompetensi untuk menjadi seorang site engineer adalah Memahami (M) dan tertinggi adalah Ahli (A).

Sejalan dengan hasil penelitian tersebut di atas, Hargiyarto, dkk (2010) mendapatkan hasil penelusuran alumni (tracer study) fakultas teknik UNY bahwa pihak industri memandang perlu adanya peningkatan kompetensi: manajerial, kepemimpinan, bahasa asing (inggris), teknologi informasi dan soft skill, sementara saran dari alumni atau lulusan FT UNY untuk pengembangan kompetensi lulusan dalam bidang industri/produksi, meliputi: perhitungan struktur, pembuatan RAB sampai Penerapan di lapangan; cara menggambar yang benar, AUTOCAD, SAP; kemampuan identifikasi komponen, kemampuan melakukan overhaul dan kemampuan analisa gangguan/trouble shooting.

\section{Relevansi Kompetensi di Dunia Kerja dan Perguruan Tinggi}

Kompetensi lulusan D3 Teknik Sipil secara umum adalah: (1) mampu melakukan desain gambar bangunan sipil baik secara manual maupun secara komputerisasi; (2) mampu menghitung analisa anggaran biaya; (3) mampu melakukan survey (pengukuran dan pemetaan suatu lahan); (4) mampu me- 
nyusun administrasi proyek; (5) Mampu menyusun dokumen lelang; dan (6) Mampu melakukan pengawasan pekerjaan suatu proyek konstruksi.

Walaupun permasalahan terkait Link and Match masih cukup berat, negara lain yang sudah maju sekalipun masih menghadapi masalah antara keluaran dari pendidikan dengan kebutuhan dunia industri, hanya saja mereka berusaha setiap tahun memperkecil "gap" tersebut dengan mengevaluasi dan memperbaiki sistem pendidikan yang dijalankan. Dengan magang langsung di industri, semua peralatan dan kebutuhan perusahaan selalu up to date, sehingga tidak ada perbedaan antara alat peraga yang ada di sekolah dengan yang ada di industri (Yasar, 2009).

Relevansi kompetensi lulusan dengan kompetensi di dunia kerja dijabarkan pada aspek technical skills dan employability skills sebagai berikut:

\section{Technical Skills}

Relevansi kompetensi lulusan disesuaikan dengan industri tempat mereka bekerja. Hasil penelitian ini menunjukkan bahwa bidang pekerjaan yang didominasi lulusan D3 Teknik Sipil UNM adalah sebagai kontraktor (golongan besar, menengah, dan kecil) sebesar $35 \%$, sebagai developer (besar dan menengah) sebesar $20 \%$, sebagai konsultan $10 \%$, sebagai PNS $10 \%$, wiraswasta dan lainnya $10 \%$, dan yang masih menganggur sebesar $10 \%$. Relevansi kompetensi lulusan pada industri tempat mereka bekerja dapat dilihat pada Gambar 3.

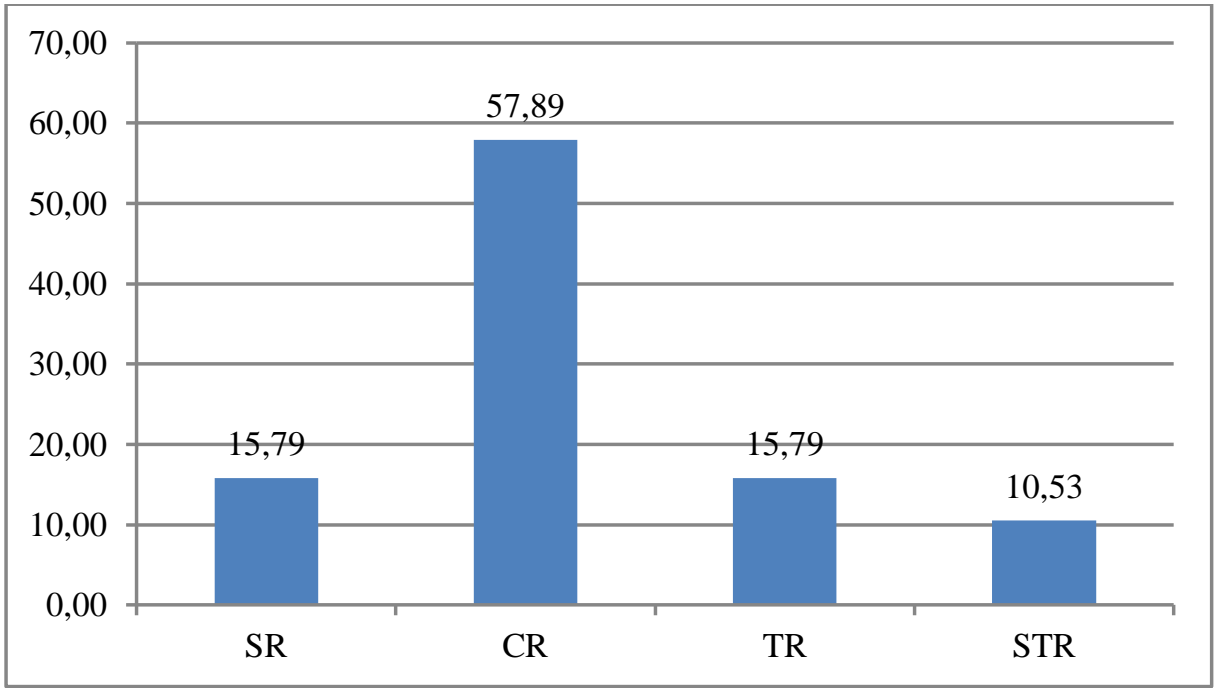

Gambar 3. Relevansi Technical Skills Lulusan

SB: sangat relevan;

TB: tidak relevan;
CB: cukup relevan;

STR: sangat tidak relevan
Dari Gambar 3 terlihat bahwa tingkat relevansi technical skills lulusan berada pada level cukup relevan dengan nilai sebesar $57,89 \%$ dan sangat relevan sebesar $15,79 \%$. Banyaknya lulusan yang memiliki relevansi kompetensi yang mencapai $73,68 \%$ merupakan sumbangsih dari lulusan yang bekerja pada dunia konstruksi. Secara umum mereka memiliki relevansi kompetensi technical skills yang cukup bagus. Dari data keterampilan lulusan yang tidak relevan sebesar $15,79 \%$ bahkan sangat tidak relevan sebesar $10,53 \%$ berasal dari lulusan yang tidak bekerja pada industri konstruksi.

Walaupun lulusan telah memperoleh keterampilan teknis pada pembelajaran di kampus, namun kebanyakan lulusan berpendapat bahwa mereka lebih banyak mendapatkan keterampilan teknis di tempat mereka bekerja. Hal ini harus menjadi perhatian bagi perguruan tinggi dalam menghasilkan lulusan yang belum siap pakai dan siap kerja karena industri masih perlu memberikan keterampilan tambahan hampir separuh keterampilan yang dibutuhkan dunia kerja. Karena itu, 
model pembelajaran di kampus harus berorientasi dunia kerja nyata sehingga lulusan yang dihasilkan pun harus bisa siap kerja dan siap pakai oleh dunia industri. Relevansi technical skills lulusan secara lebih detail dapat dilihat pada Tabel 3.

Tabel 3. Relevansi Technical Skills Lulusan

\begin{tabular}{|c|c|c|c|c|c|}
\hline No & Tugas & SR & CR & TR & STR \\
\hline 1 & Mengetahui bidang pekerjaan & 25,00 & 50,00 & 25,00 & - \\
\hline 2 & Menggambar manual & 12,50 & 62,50 & 25,00 & - \\
\hline 3 & Menggambar menggunakan computer & 12,50 & 62,50 & 25,00 & - \\
\hline 4 & Menghitung RAB secara manual (kalkulator) & - & 75,00 & 25,00 & - \\
\hline 5 & Menghitung RAB menggunakan computer & 12,50 & 75,00 & - & 12,50 \\
\hline 6 & Mengidentifikasi kesalahan perhitungan RAB & 12,50 & 75,00 & - & 12,50 \\
\hline 7 & Mengevaluasi kelayakan RAB & 12,50 & 62,50 & 12,50 & 12,50 \\
\hline 8 & Mengoperasikan Alat/Mesin & - & 62,50 & 25,00 & 12,50 \\
\hline 9 & Memelihara Alat/Mesin & - & 62,50 & 25,00 & 12,50 \\
\hline 10 & Memperbaiki Alat/Mesin & - & 50,00 & 12,50 & 37,50 \\
\hline 11 & Mengidentifikasi Kerusakan Alat/Mesin & 12,50 & 25,00 & 25,00 & 37,50 \\
\hline 12 & Membaca gambar kerja & 37,50 & 62,50 & - & - \\
\hline 13 & Menjelaskan gambar kerja kepada tukang & 37,50 & 50,00 & 12,50 & - \\
\hline 14 & Mengawasi pekerjaan sesuai jadwal & 37,50 & 37,50 & 12,50 & 12,50 \\
\hline 15 & Membuat laporan pengawasan pekerjaan & 37,50 & 50,00 & 12,50 & - \\
\hline 16 & Merevisi kesalahan pada pekerjaan & 12,50 & 62,50 & 25,00 & - \\
\hline 17 & Mengevaluasi pelaksanaan pekerjaan & 25,00 & 62,50 & - & 12,50 \\
\hline 18 & Menyusun dokumen tender & - & 62,50 & 25,00 & 12,50 \\
\hline 19 & Melakukan pekerjaan survey & 12,50 & 50,00 & 12,50 & 25,00 \\
\hline
\end{tabular}

Sumber: Hasil Penelitian, 2011

Tabel 3 menunjukkan bahwa hampir seluruh komponen technical skills terdapat pendapat yang mengatakan bahwa keterampilan lulusan tidak relevan, bahkan sangat tidak relevan. Selain itu, relevansi terendah dalam hal ini sangat tidak relevan terlihat pada point 10 dan 11 yang terkait dengan peralatan, sedangkan relevensi tertinggi dalam hal ini sangat relevan terlihat pada point $12,13,14$, dan 15 yang terkait dengan gambar kerja, pengawasan, dan pembuatan laporan. Sementara secara umum, keterampilan lulusan dalam hal teknis masih cukup relevan dengan keterampilan di industri. Pekerjaan-pekerjaan yang bersifat manual telah menjadi perhatian dari industri konstruksi. Sebagian besar industri sudah tidak menggunakan pekerjaan manual sebagai bagian dari pekerjaan keseharian mereka, sehingga lulusan tidak lagi dihadapkan pada pekerjaan manual melainkan pada pekerjaan yang bersifat komputerisasi dan digital. Karena itu, pengembangan pembelajaran dalam bidang teknologi harus menjadi bagian penting dalam membekali lulusan menghadapi dunia kerja.

\section{Kemampuan Employability Skills}

Seperti yang disebutkan sebelumnya bahwa bidang pekerjaan lulusan pada insutri konstruksi sebesar 65\%, menjadi PNS 10\%, dan sisanya $25 \%$ pada bidang lainnya termasuk yang masih menganggur. Kemampuan employability skills merupakan penilaian diri mereka sendiri dalam melihat kemampuannya sendiri. Untuk lebih jelasnya dapat dilihat pada Gambar 4. 


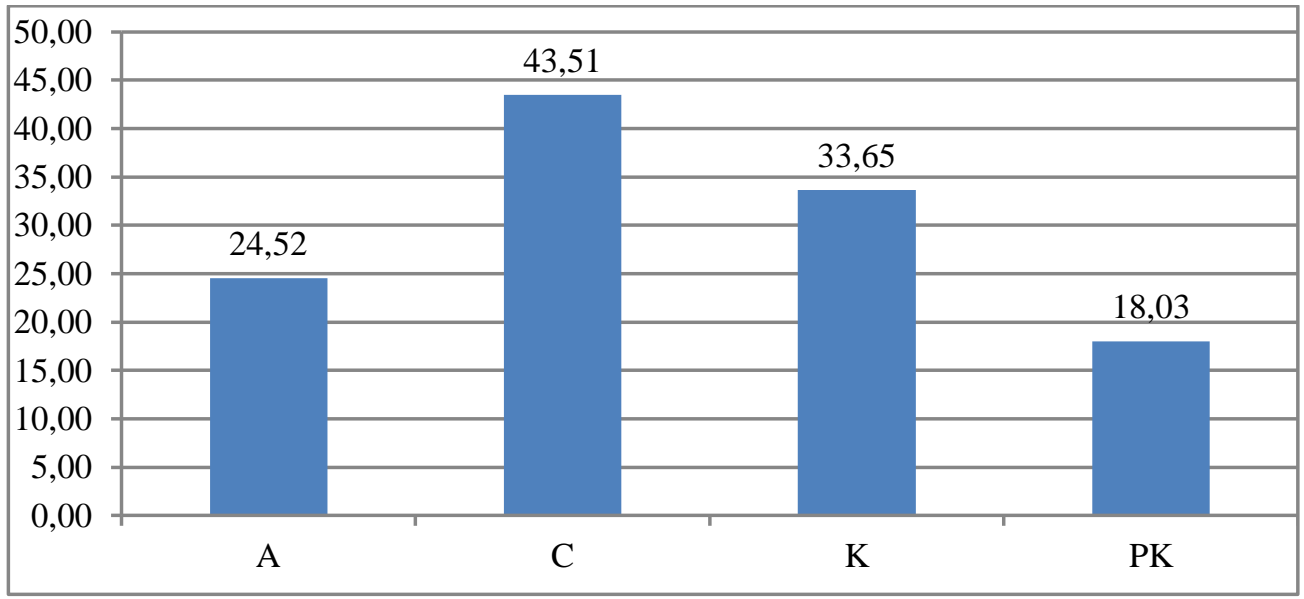

Gambar 4. Kemampuan lulusan dalam hal employability skills

A: Ahli; $\quad$ C: Cakap;

K: Kompeten; PK: Perlu dikembangkan

Dari Gambar 4 memperlihatkan bahwa lulusan yang masuk kategori Ahli sebesar $24,52 \%$ sementara yang cakap sebesar $43,51 \%$ dan kompeten sebesar $33,65 \%$. Namun demikian, masih terdapat $18,03 \%$ lulusan yang masih perlu dikembangkan. Kemampuan lulusan yang masuk kategori Ahli jika lulusan telah memahami keterampilan tersebut dan setiap saat digunakan dalam bekerja, kategori Cakap jika lulusan memahami keterampilan tersebut namun tidak setiap saat digunakan dalam bekerja, kategori Kompeten dipilih jika lulusan memahami keterampilan tersebut namun jarang digunakan karena bidang pekerjaannya kemungkinan tidak menuntut adanya keterampilan tersebut, sementara kategori Perlu dikembangkan dipilih jika lulusan belum memahami keterampilan tersebut dan jarang digunakan dalam setiap aktivitas pekerjaannya. Untuk lebih detail melihat komponen employability skills dapat dapat dilihat pada Tabel 4.

Tabel 4. Kemampuan Employability Skills Lulusan

\begin{tabular}{lrrrr}
\hline \multicolumn{1}{c}{ Komponen employability skills } & Ahli & Cakap & Kompeten & $\begin{array}{c}\text { Perlu } \\
\text { dikembangkan }\end{array}$ \\
\hline Komunikasi & 19,64 & 30,36 & 32,14 & 17,86 \\
Kerja Tim & 20,00 & 30,00 & 27,50 & 22,50 \\
Pemecahan Masalah & 16,67 & 29,17 & 37,50 & 16,67 \\
Manajemen Diri & 27,50 & 35,00 & 37,50 & 0,00 \\
Perencanaan dan Pengelolaan & 18,75 & 39,06 & 25,00 & 17,19 \\
Teknologi & 22,92 & 43,75 & 20,83 & 12,50 \\
Belajar Sepanjang Hayat & 25,00 & 41,07 & 32,14 & 1,79 \\
Inisiatif dan Keberanian Berusaha & 12,50 & 54,69 & 23,44 & 9,37 \\
\hline
\end{tabular}

Sumber: Hasil Penelitian, 2011

Tabel 4 menunjukkan bahwa hampir seluruh komponen employability skills lulusan telah masuk kategori Cakap dengan kemampuan tertinggi pada komponen inisiatif dan keberanian berusaha, bahkan komponen manajemen diri dengan kategori Ahli berada pada posisi tertinggi sebesar $27,5 \%$. Namun demikian, masih terdapat kemampuan lulusan 
yang perlu dikembangkan terutama pada komponen keterampilan kerja tim, komunikasi, perencanaan dan pengelolaan, pemacahan masalah, teknologi, dan keterampilan inisiatif dan keberanian berusaha.

Dalam hal kemampuan employability skills lulusan terlihat sudah sangat bagus, hanya saja masih perlu dikembangkan sekitar $18 \%$. kemampuan lulusan yang perlu dikembangkan terutama pada komponen keterampilan kerja tim, komunikasi, perencanaan dan pengelolaan, pemacahan masalah, teknologi, dan keterampilan inisiatif dan keberanian berusaha. Dari hasil ini, kemudian kita sesuaikan dengan tempat mereka mendapatkan keterampilan tersebut dan ternyata bahwa hanya $21,63 \%$ lulusan yang mengatakan bahwa mereka mendapatkan employability skills pada pembelajaran dikampus, selebihnya mereka dapatkan pada organisasi sebesar 32,69\% bahkan $44,71 \%$ lulusan berpandangan bahwa mereka mendapatkan employability skills nanti setelah mereka bekerja.

Dari uraian tersebut di atas, menunjukkan bahwa kualitas pembelajaran di kampus masih sangat rendah dan perlu dilakukan perbaikan dan pengembangan sehingga lulusan perguruan tinggi terutama Jurusan Pendidikan Teknik Sipil dan Perencanaan memiliki kompetensi yang dapat bersaing di dunia kerja. Perbaikan yang dilakukan bisa saja dalam bentuk pengembangan model pembelajaran yang mendekatkan mahasiswa dengan dunia kerja nyata serta memberikan bekal-bekal kecakapan hidup (life skills) untuk dapat beradaptasi pada lingkungan kerja manapun dan kapanpun.

Kesenjangan kompetensi yang ada menunjukkan perlunya pihak perguruan tinggi untuk lebih merelevansikan kualitas lulusannya dengan kebutuhan dunia kerja. Hal tersebut terkait dengan apa yang dikemukakan oleh Abduh, Biemo, \& Reini (2008) yang menyimpulkan bahwa kesenjangan kompetensi lulusan pendidikan vokasi diploma 3 (D3) terhadap persyaratan kompetensi keahlian yang ditetapkan oleh LPJK (SKA) ternyata masih cukup tinggi. Hal ini terjadi karena tampaknya bakuan kompetensi keahlian LPJK mengacu pada kompetensi hasil pendidikan dengan kurikulum yang setara dengan pendidikan 4 tahun. Hal yang sama juga terjadi pada jenjang pendidikan vokasi D4, padahal pendidikan D4 lebih mengarah kepada penajaman pada bidang tertentu (konsentrasi).

Pemikiran lain dikemukakan oleh Dardiri (2011) yang menjelaskan bahwa untuk meningkatkan daya saing lulusan pendidikan teknik bangunan (PTB) perlu dilakukan diversifikasi kompetensi lulusan dengan meningkatkan relevansi kurikulum berorientasi peningkatan kompetensi dasar kepribadian; (2) penerapan model pembelajaran berbasis TQM dapat meningkatkan daya saing lulusan; (3) penguatan kerjasama magang/kemitraan dalam pembelajran akan meningkatkan daya saing lulusan; dan (4) kepemimpinan memiliki peran strategis dalam restrukturisasi kurikulum berbasis keunggulan kepribadian dan rekulturisasi pembelajaran tradisional ke pembelajaran berbasis mutu.

\section{SIMPULAN}

Kompetensi lulusan yang dibutuhkan dunia industri masih tetap pada penguasaan keterampilan teknis (technical skills) sebesar 47,37\% dengan lebih mengedepankan tugastugas yang terkait dengan komputerisasi dan digital dibandingkan tugas-tugas yang bersifat manual, serta keterampilan bekerja (employability skills) sebesar $58,21 \%$ yang lebih cenderung pada aspek komunikasi, inisiatif dan keberanian berusaha, dan kemampuan untuk bekerja secara tim.

Relevansi kompetensi di dunia kerja dengan kompetensi lulusan yang merupakan hasil dari perguruan tinggi pada aspek technical skills termasuk kategori cukup relevan sebesar 73,68\%, namun masih terdapat 26,32\% yang tidak relevan lagi. Employability skills sebagian kecil lulusan $(24,52 \%)$ masuk kategori Ahli, hanya saja mereka lebih banyak mendapatkan hal tersebut bukan melalui pembelajaran dikampus melainkan setelah mereka bekerja, sementara mayoritas kemampuan lulusan berada pada kategori Cakap yakni sebesar $43,51 \%$.

\section{DAFTAR PUSTAKA}

Abduh, M., Biemo, W.S., \& Reini D.W. (2008). "Kesenjangan antar kompetensi pendidikan tinggi dengan kompetensi keahlian konstruksi". Makalah disampaikan pada Konferensi Nasional Teknik Sipil 2 (KoNTekS 2) - 
Universitas Atma Jaya Yogyakarta Yogyakarta, 6 - 7 Juni 2008

Benyamin, A.N.N. \& Lanny (2002). Skripsi. Kriteria fresh graduate teknik sipil dalam memasuki dunia kerja di perusahaan kontraktor kelas A di Surabaya. Surabaya: Universitas Kristen Petra Surabaya.

BPS. (2010). Laporan Bulanan Data Sosial Ekonomi. Jakarta : BPS

Dardiri, Ahmad. (2011). "Diversifikasi kompetensi lulusan pendidikan dan latihan vokasi untuk lebih kompetitif". Jurnal Teknologi dan Kejuruan Vol. 34 No. 1 Pebruari 2011:91-104.

Finch, C. R., \& Crunkilton, J. R. (1999). Curriculum Development in Vocational and Technical Education: Planning, Content and Implementation $5^{\text {th }} \mathrm{Ed}$. Boston, Massachusetts: Allyn \& Bacon, Inc.
Hargiyarto, P., Sugiman, \& Nurkholis. (2010). Studi penelusuran lulusan Fakultas Teknik Universitas Negeri Yogyakarta yang bekerja di dunia industri. Yogyakarta: Lembaga Penelitian

Mukminan, Waras K., Herminarto S., et el. (2008). Panduan Pengembangan Model Pembelajaran Berbasis Kompetensi. Jakarta: Dikti

Tilaar, H.A.R. (1991). "Sistem Pendidikan Yang Modern Bagi Pembangunan Masyarakat Industri Modern Berdasarkan Pancasila”. Makalah pada KIPNAS V September 1991, Jakarta.

Yasar, Iftida. (2009). Link and match: Keterkaitan dunia industri dan dunia pendidikan. Dari http://indosdm.com/ link-and-match-keterkaitan-duniaindustri-dan-dunia-pendidikan Diunduh 5 januari 2011. 